\title{
A METAFísica ENgUANTO INSTÂNCIA FONTAL DA FILOSOFIA NO PENSAMENTO DE LIMA VAZ
}

(Metaphysics as the basic element of philosophy in Lima Vaz's thinking)

\author{
Manfredo Araújo de Oliveira*
}

Resumo: A filosofia na tradição procurou pensar o todo da realidade a partir da verdade profunda de suas razões e do Princípio que as unifica e explica o que justifica sua presença ao mesmo tempo necessária e paradoxal no meio do mundo por ter como tarefa o confronto com as questões últimas sobre o ser, a verdade e o bem. Com isso ela se faz a instância crítica e sistemática privilegiada das diversas formas de cultura e a articulação de uma ordem de razões que se radica em última instância na posição de um Absoluto como Princípio rigorosamente pensado e capaz de sustentar uma nova visão do todo. A modernidade significa a inversão radical do modelo conceitual que marcou o pensamento clássico pela imanentização do teológico no histórico com consequências graves na vida teórica e prática. $\mathrm{O}$ enorme desafio de hoje consiste em recuperar teoricamente em situações muito diferentes o que constituiu o cerne do pensamento metafísico ocidental

Palavras-chave: Metafísica, princípio unificante, modernidade, desafio atual, Lima Vaz.

Abstract: Traditional philosophy sought to think the whole of reality through the deep truth of its reasons and through the Principle that unifies and explains them. That is what justifies the necessary but paradoxical presence of philosophy

\footnotetext{
* Doutor em Filosofia pela Ludwig Maximilians Universität München, Alemanha. Professor Titular do Departamento de Filosofia da Universidade Federal do Ceará, Fortaleza, CE, Brasil. Artigo submetido a avaliação no dia 14.03.2012 e aprovado para publicação no dia 25.05.2012.
} 
in the midst of the world, since its task is to confront the ultimate questions about the being, truth and good. Philosophy thus becomes the systematic and critical instance of the most diverse forms of culture and the articulation of an order of reasons which ultimately stems from an Absolute taken as a Principle which is rigorously thought out and capable of supporting a new understanding of totality. Modernity is the radical opposite of the conceptual model that marked classical thinking, by the immanentization of the theological realm into the historical one, entailing serious consequences in theoretical and practical life. The main challenge today is to recover theoretically, and in very different situations, what is at the heart of Western metaphysical thinking.

Keywords: Metaphusics, unifying principle, modernity, present challenge, Lima Vaz.

$\mathrm{A}$ filosofia, para Lima Vaz, tem uma relação muito íntima com o tempo e como todo pensamento autêntico, ela é progressiva e cri adora. ${ }^{1}$ Assim, como o ser humano, ela vive em primeiro lugar da força da tradição, da consciência de uma continuidade viva com o passado. ${ }^{2}$ Mas por outro lado, o ser humano é sempre inserido em mundos históricos diferenciados e isto traz para a reflexão filosófica a convergência de duas dimensões irrenunciáveis: o filósofo situado numa epocalidade específica tem como primeiro desafio "adivinhar na face nova das aporias concretas que solicitam o espírito, sob a conjunção de dado céu histórico, os traços antigos desses problemas que bem se chamam "eternos" e cuja permanência é como o signo que revela a constância de nossa natureza e a unidade de nosso destino". ${ }^{3}$ Trata-se para Lima Vaz das grandes questões sobre o ser, o sentido e o destino. Eternidade e Epocalidade convidam a filosofia a uma eterna reinvenção de si mesma na busca "de recriar o mundo das coisas e o mundo dos homens à luz de um logos que julga, demonstra, ordena e unifica". ${ }^{4}$ Daí a tarefa que se põe ao filósofo de hoje de se perguntar pelo projeto filosófico da modernidade.

\footnotetext{
${ }^{1}$ Cf. LIMA VAZ H. C. de, Itinerário da Ontologia Clássica, in: Escritos de Filosofia VI, Ontologia e História, São Paulo: Loyola, 2001, p.57. Mac Dowell J. A., Método Dialético, História e Transcendência no Sistema Filosófico de Henrique de Lima Vaz, in: CARDOSO D. (Org.), Pensadores do Século XX, São Paulo: Loyola/Paulus, 2012, p. 222: “Assim o progresso da filosofia apresenta-se como uma permanente reinvenção, onde se conjugam continuidade e descontinuidade, não repetição mecânica do já dito, mas iniciativa de sua inteira reproposição sob a forma de espontânea criação".

${ }^{2}$ Cf. LIMA VAZ H. C. de, Morte e Vida da Filosofia, in: Síntese, v. 18, n. 55 (1991) 684-685: “Mas a filosofia assume como tarefa pensar tematicamente sue próprio passado - unir anámnesis e nóesis - e, nessa rememoração pensante, reinventar os problemas que lhe deram origem e, assim, cumprir o destino que, ainda segundo Hegel, está inscrito em sua própria essência: captar o tempo no conceito - o tempo que foi e o tempo que flui no agora do filosofar".

${ }^{3}$ Cf. LIMA VAZ H. C. de, Itinerário da Ontologia Clássica, op. cit., p. 58.

${ }^{4}$ Cf. LIMA VAZ H. C. de, Filosofia e Cultura: Perspectiva Histórica, in: Escritos de Filosofia III, Filosofia e Cultura, São Paulo: Loyola, 1997, p. 16.
} 


\section{1) A situação dramática espiritual e intelectual gerada pela Metafísica da Subjetividade da Modernidade}

Em que consiste fundamentalmente o projeto teórico da modernidade? Para Lima Vaz numa "inversão radical" do modelo conceitual que marcou o pensamento clássico. A ideia da inversão pressupõe a compreensão que tem Lima Vaz da estrutura teórica básica do pensamento do Ocidente, que para ele já se manifesta em seu núcleo basilar no propósito teórico de Parmênides de pensar a unidade profunda da realidade em seu todo e, portanto, de compreender a gênese e a explicação do múltiplo a partir dessa unidade originária o que o conduz a pensar o ser e a pensá-lo como absoluto. Dessa forma ele foi o iniciador da ontologia enquanto ciência do Ser e dos seres, ciência do inteligível, ciência das razões do $\operatorname{ser}^{5}$ que encontrou na história do Ocidente várias versões e que a partir de Platão se articulou de forma dialética.

O filósofo aparece nesse contexto, como se vai explicitar no desenvolvimento posterior dessa ciência, como aquele que tem competência para curar a patologia de um múltiplo desordenado e dividido em que os seres humanos se perdem e para articular o modelo de inteligibilidade do mundo humano a partir da ordem do múltiplo que procede da unidade última. Ela emerge num mundo humano já sempre marcado por razões de viver, de crer, de pensar, de agir e de suas aporias.

Nesse contexto, a filosofia procura "provocar a conversão desse universo à verdade profunda de suas razões e ao Princípio que as unifica e expli$\mathrm{ca}^{\prime \prime}{ }^{6}$ o que justifica sua presença ao mesmo tempo necessária e paradoxal no meio do mundo precisamente por ter como tarefa o confronto com as questões últimas sobre o ser, a verdade e o bem. Com isso ela se faz "a instância crítica e sistemática privilegiada das diversas formas de cultura" ${ }^{7}$ e a articulação de uma ordem de razões que se radica em última instância na "posição de um Absoluto como Princípio rigorosamente pensado" ${ }^{8} \mathrm{e}$ capaz de sustentar uma nova visão do todo.

Dessa forma, a filosofia já se revela desde o início "como pensamento do uno na multiplicidade dos discursos e dos seus objetos", ${ }^{9}$ portanto, como

\footnotetext{
${ }^{5}$ Cf. LIMA VAZ H. C. de, Esquecimento e Memória do Ser: Sobre o Futuro da Metafísica, in: Escritos de Filosofia VII, Raízes da Modernidade, op. cit., p. 275.

${ }^{6}$ Cf. LIMA VAZ H. C. de, Cf. LIMA VAZ H. C. de, Filosofia e Cultura: Perspectiva Histórica, op. cit., p. 21.

${ }^{7}$ Cf. LIMA VAZ H. C. de, Cf. LIMA VAZ H. C. de, Filosofia e Cultura: Perspectiva Histórica, op. cit., p. 46.

${ }^{8}$ Cf. LIMA VAZ H. C. de, Cf. LIMA VAZ H. C. de, Filosofia e Cultura: Perspectiva Histórica, op. cit., p. 78.

${ }^{9}$ Cf. LIMA VAZ H. C. de, Cf. LIMA VAZ H. C. de, Filosofia e Cultura: Perspectiva Histórica, op. cit., p. 12.
} 
saber do todo e de seu princípio e, assim, saber de si mesma, de seu lugar e de sua significação no seio do todo. É isso que a faz capaz de "reconduzir o disperso do mundo dos homens à sua unidade e ao seu ser verdadeiro"10 o que faz com que sua estrutura fundamental seja uma dialética do uno e do múltiplo.

A grande questão de fundo de uma teoria do ser em seu todo, a oposição do uno e do múltiplo, foi traduzida na oposição básica do Absoluto e do relativo. Nesse contexto um traço comum entre as concepções desenvolvidas no seio do pensamento grego e a tradição cristã é a intuição da transcendência do ser enquanto inteligível primeiro separado da limitação essencial dos entes finitos e relativos.

Assim, o que caracteriza este quadro teórico é que aqui o Esse absoluto possui centralidade, isto é, "anterioridade objetiva" (p. 100) enquanto causa do ser sobre sua afirmação pela subjetividade finita. Isso implica dizer que a subjetividade não constitui a razão última de possibilidade dessa intuição o que liberta o pensamento clássico de uma contradição autodestrutiva na medida em que assim o Esse absoluto não é relativizado na imanência do sujeito ${ }^{11}$ o que implicaria a negação de sua absolutidade.

Ao contrário, neste quadro teórico a inteligência finita é ela mesma compreendida no horizonte da inteligibilidade absolutamente universal do $E_{s s e^{12}}$ e é o Esse a fonte última de inteligibilidade da inteligência finita e não essa a fonte de inteligibilidade do Esse. Nesta postura, consequentemente, a estrutura constitutiva dos entes finitos só pode ser compreendida enquanto estrutura participada no Esse absoluto, o Esse subsistente que, enquanto tal, revela sua transcendência radical seja em relação ao esse dos seres relativos seja em relação à sua expressão na inteligência finita.

Filosoficamente a modernidade significa, então, para Lima Vaz a "passagem decisiva do regime gnosiológico do ser ao regime gnosiológico da representação", ${ }_{13}^{13}$ portanto, passagem para outro regime noético-especulativo fundado na primazia da representação sobre o ser o que vai fazer "refluir

\footnotetext{
${ }^{10}$ Cf. LIMA VAZ H. C. de, Cf. LIMA VAZ H. C. de, Filosofia e Cultura: Perspectiva Histórica, op. cit., p. 15.

${ }^{11}$ Cf. LIMA VAZ H. C. de, Transcendência : Experiência Histórica e Interpretação Filosóficoteológica, in: Síntese v. 19 n. 59 (1992) 446: “Descobrir o Absoluto na imanência do sujeito: esse o enjeu profundo e decisivo do problema da transcendência tal como se apresentou, de Platão a Hegel, a toda a tradição filosófica".

12 Por isso, para Lima Vaz, "como ensina Tomás de Aquino, um ser que assume o infinito ônus metafísico de enunciar o existir dos seres só pode existir autenticamente ao assumir sua abertura constitutiva ao Absoluto: no consentimento às formas absolutas da Verdade e do Bem e no reconhecimento da ordenação de todo o seu ser ao Existir transcendente absoluto". Cf. LIMA VAZ H. C. de, Filosofia e Cultura: Perspectiva Histórica, op. cit., p. 342.

${ }^{13}$ Cf. LIMA VAZ H. C. de, A Metafísica na Modernidade, in: Filosofia e Cultura: Perspectiva Histórica, op. cit., p. 351.
} 
para o sujeito o princípio último da fundamentação do ser"14 de tal maneira que o sujeito se torna o centro organizador do mundo simbólico. ${ }^{15} \mathrm{~Pa}-$ rafraseando a famosa explicação que Heidegger dá a Jean Beaufret na Carta sobre o Humanismo ${ }^{16}$ a respeito da diferença de seu pensamento em relação ao pensamento de Sartre podemos dizer, para exprimir a intuição básica de Lima Vaz sobre o pensamento moderno, que o que importa na modernidade não é o Esse, mas a subjetividade finita ${ }^{17}$ agora considerada o "primum ontologicum da inteligibilidade do ser". ${ }^{18}$

Numa palavra, o pensamento filosófico moderno leva a metafísica clássica do ser à metafísica da subjetividade. Aqui o problema fundamental não é mais o "Primeiro Ser" (primum ens), mas o Primeiro Conhecido (primum cognitum), ou seja, o problema não é mais a respeito do Transcendente, mas das condições transcendentais de possibilidade do conhecimento de qualquer objeto. Isso vai implicar uma reestruturação profunda do universo simbólico da civilização ocidental uma vez que vai transformar pelas raízes nossa concepção de realidade e nossa relação com ela.

Para Lima Vaz essa reviravolta antropocêntrica do pensamento evoluiu na medida em que "a iniciativa instituidora do mundo humano atribuída ao sujeito transcendental tende a transferir-se para os grandes sistemas do saber, da práxis e da técnica que se estruturam segundo o modelo da subjetividade, como subjetividades universais, no seio das quais o indivíduo pensa, age e produz". ${ }^{19}$

Um bom exemplo disso é para ele justamente o sistema sempre mais abrangente da tecnociência, pois a inversão significa epistemologicamente a integração completa do todo da realidade, da natureza, da vida, do ser humano e seu agir no quadro teórico da razão científica: “O verdadeiro coração teórico da modernidade é o projeto de extrema audácia, cuja execu-

\footnotetext{
${ }^{14}$ Cf. LIMA VAZ H. C. de, A Metafísica na Modernidade, op.cit., p. 350-351.

${ }^{15}$ Cf. LIMA VAZ H. C. de, Transcendência e Religião, in: Filosofia e Cultura: Perspectiva Histórica, op. cit., p. 237: “A ontologia da Metafísica clássica... sofre, portanto, a partir do projeto cartesiano, uma inversão de sentido na sua estrutura fundamental, cedendo lugar, finalmente, a uma onto-antropologia".

${ }^{16}$ Cf. HEIDEGGER M. Platons Lehre von der Wahrheit. Mit einem Brief über den "Humanismus", Bern: Francke Verlag, 1954, p. 79-80: “... wenn er Existentialismus ist und den Satz vertritt, den Sartre ausspricht: précisément nous sommes sur un plan où Il y a seulement des hommes (L`Existentialisme est un humanisme p. 36). Statt dessen wäre, von "S.u.Z." her gedacht, zu sagen: précisément nous sommes sur un plan où Il y a principalement l'Être".

${ }^{17}$ Cf. LIMA VAZ H. C. de, Transcendência e Religião, in: Filosofia e Cultura: Perspectiva Histórica, op. cit., p. 238-239: “No paradigma da metafísica moderna, a descentração se dá com relação ao lugar do homem no mundo... Mas, a essa descentração tópica corresponde uma recentração no plano metafísico, segundo a qual o homem, como sujeito, passa a ocupar o centro do universo inteligível".

${ }^{18}$ Cf. LIMA VAZ H. C. de, A Metafísica na Modernidade, op. cit., p. 365.

${ }^{19}$ Cf. LIMA VAZ H. C. de, O Problema da Criação, op. cit., p. 144.
} 
ção vem transformando radicalmente a vida humana nos últimos quatro séculos, que tem em vista a plena reinscrição, teórica e operacionalmente, nos códigos da razão científica, do universo, da vida, do ser humano e das suas condutas".$^{20}$

Nessa perspectiva o pensamento moderno para Lima Vaz se caracteriza em seu núcleo último como um imanentismo radical, como o projeto de construção da "cidade do homem". ${ }^{21}$ Aqui as grandes questões metafísicas, ${ }^{22}$ as questões básicas da vida humana enquanto tal, vão encontrar uma solução na "racionalidade sistêmica como estrutura simbólica básica da nossa civilização", 23 "a forma determinante do estilo de civilização" 24 que nos marca. Daí porque a modernidade do ponto de vista da racionalidade é em seu cerne razão científica, ou seja, razão que se configura como uma racionalidade voltada ao operar do ser humano no mundo direcionado à produção eficaz de objetos o que significa dizer que "as estruturas da techne substituem progressivamente a ordem natural do kosmos". ${ }^{25}$ Seu grande objetivo é alcançar "perfeita homologia na ordem do conhecer e do fazer entre o ser humano e o mundo por ele transformado". ${ }^{26}$

Modernidade significa, portanto, primazia daquela forma de razão que Lima Vaz chama de operacional (a razão instrumental dos frankfurtianos) e constitui a mediação privilegiada da atividade poiética do sujeito no mundo seja na construção do próprio saber, seja na construção dos objetos. Para ele a primazia da razão operacional é uma consequência necessária do postulado epistemológico básico de que a razão conhece o real "na representação da ideia objetiva" ${ }^{27}$ que constitui o objeto próprio do ato de conhecimento. Nisso se revela com clareza o específico da razão moderna: ela se faz "a instituidora originária do universo das razões".$^{28}$ Isso constitui o ponto de partida da metafísica da subjetividade, o quadro teórico hegemônico na modernidade.

\footnotetext{
${ }^{20}$ Cf. LIMA VAZ H. C. de, A Metafísica em questão, in: Escritos de Filosofia VII, Raízes da Modernidade, São Paulo: Loyola, 2002, p. 98-99.

${ }^{21}$ Cf. SAMPAIO R. G., Metafísica e Modernidade método estrutura, temas e sistema em Henrique Cláudio de Lima Vaz, São Paulo: Loyola, 2006, p. 208 e ss.

${ }^{22}$ Cf. SAMPAIO R. G., Metafísica e Modernidade, op. cit., p. 190: “Essa estrutura analógica da Razão foi rompida. E com isso os modelos de racionalidade da física e da matemática, da dialética, da lógico-linguística, da fenomenologia e da hermenêutica começaram a reivindicar o posto antes ocupado pela antiga razão metafísica, sem contudo alcançar uma forma de unificação do campo da razão".

${ }^{23}$ Cf. LIMA VAZ H. C. de, Filosofia e Cultura: Perspectiva Histórica, op. cit., p. 78.

${ }^{24}$ Cf. LIMA VAZ H. C. de, Presença de Tomás de Aquino no horizonte filosófico do século XXI, in: Escritos de Filosofia VII, Raízes da Modernidade, op. cit, p. 253.

${ }^{25}$ Cf. LIMA VAZ H. C. de, Fisionomia do século XIII, in: Escritos de Filosofia I - Problemas de Fronteira, São Paulo: Loyola, 1986, p. 38.

${ }^{26}$ Cf. LIMA VAZ H. C. de, Presença de Tomás de Aquino no horizonte filosófico do século XXI, op. cit, p. 253.

${ }^{27}$ Cf. LIMA VAZ H. C. de, A Metafísica em questão, op. cit., p. 102.

${ }^{28}$ Ibid
} 
Aparentemente isso significa um abandono radical do grande paradigma que marcou toda a história do Ocidente até a modernidade. Paradoxalmente, contudo, e esta é a tese fundamental de Lima Vaz a respeito da Modernidade, ele significa uma inversão radical do pensamento clássico na medida em que é "a construção de um absoluto no interior do próprio devir histórico" 29 de tal forma que "o horizonte da imanência torna-se, para o homem moderno, o único horizonte englobante de toda a realida$\mathrm{de}^{\prime \prime}{ }^{30}$ Para ele essa inversão ocorre "na transposição, para a imanência histórica, da mesma estrutura dialética que atribuímos à relação entre o Esse absoluto e os esse relativos", ${ }^{11}$ ou seja, trata-se aqui de um "imenso processo de imanentização do teológico no histórico". ${ }^{32}$ Daí seu problema especulativo central: pensar "um absoluto que se exterioriza no movimento mesmo que o constitui". ${ }^{33}$

Assim, o horizonte metafísico de fundo reaparece em forma problemática na questão básica do pensamento moderno: é possível reconduzir a existência desde o simples ato de existir à razão humana entendida com a fonte última de toda inteligibilidade ${ }^{34}$ Pode a razão humana reivindicar os atributos do Esse subsistente? Essas perguntas revelam para Lima Vaz a estrutura teórica que especifica o pensamento moderno enquanto inversão teórica radical da metafísica clássica, pois essa em sua estrutura teórica constitutiva aponta para a transcendência absoluta do Esse enquanto que a metafísica moderna da subjetividade aponta para a imanência da representação, ${ }^{35}$ ou seja, constitui o sujeito transcendental como instância última inteligibilidade.

Essa primazia dada à razão operacional trouxe consequências profundas à autocompreensão do ser humano, pois dar primazia à razão operacional significa dar primazia à "relação de objetividade na forma da compreensão explicativa da Natureza, na efetivação do ser-em-relação do homem moderno".$^{36}$ Como a objetividade mundana é nosso primeiro encontro com o ser e a primeira experiência de nossa finitude, uma mudança profunda da objetividade mundana provoca uma mudança não menos profunda "do estatuto natural ou ôntico do nosso ser-no-mundo e, portanto, de sua inteligibilidade ontológica". ${ }^{37}$

\footnotetext{
${ }^{29}$ Cf. LIMA VAZ H. C. de, A Metafísica em questão, op. cit., p. 99.

${ }^{30}$ Cf. LIMA VAZ H. C. de, Ser e Participação, in: Raízes da Modernidade, op. cit., p. 189.

${ }^{31}$ Cf. LIMA VAZ H. C. de, Essência e Existência, in: Escritos de Filosofia VII, Raízes da Modernidade, op. cit. p. 168.

${ }^{32}$ Cf. LIMA VAZ H. C. de, O Problema da Criação, in: Escritos de Filosofia VII. Raízes da Modernidade, São Paulo: Loyola, 2001, p. 143.

33 Ibid.

${ }^{34}$ Cf. LIMA VAZ H. C. de, A Metafísica em questão, op. cit., p. 100.

${ }^{35}$ Cf. LIMA VAZ H. C. de, A Metafísica em questão, op. cit., p. 102.

${ }^{36}$ Cf. LIMA VAZ H. C. de, Antropologia Filosófica II, São Paulo: Loyola, 1992, p. 55.

${ }^{37}$ Cf. LIMA VAZ H. C. de, Presença de Tomás de Aquino no horizonte filosófico do século $X X I$, op. cit, p. 254.
} 
A intervenção transformadora na natureza dando-lhe a forma da cultura e ampliando o domínio da cultura sobre a natureza se torna a grande meta histórica da civilização moderna inaugurando uma forma de existência histórica inteiramente nova. Ora, intervindo na natureza, o ser humano intervém em sua própria condição natural, porque ele é um ser de natureza. O que se manifesta hoje para Lima Vaz é que a forma de existir sob as normas da tecnociência deixou de ser um "programa de civilização" e se transformou na "forma definitiva de nossa civilização" que perpassa todos os campos da atividade humana no mundo e que por isso é a forma envolvente e determinante de nossa cultura. ${ }^{38}$

A modernidade se caracteriza, então, por um oscilar permanente entre a objetividade produzida pela técnica visibilizada no mundo dos objetos da produção industrial e "a objetividade dada ao ser humano na sua experiência original e fundante - experiência metafísica por definição - da transcendência do Ser sobre a finitude dos seres". ${ }^{39}$ Trata-se, portanto, de uma substituição dos seres que nos são dados pela natureza pelos objetos produzidos tecnicamente pelo ser humano, o que justifica a caracterização de nossa civilização como uma civilização eminentemente científicotecnológica.

Para Lima Vaz é essa "fascinação pelo objeto técnico" a razão que explica o esquecimento do Ser e o descrédito da metafísica que marcam o universo cultural de nossa civilização hoje deixando o espaço livre para a hegemonia do saber puramente operacional. ${ }^{40}$ Precisamente o monopólio do uso legítimo da razão pela ciência pós-galileiana e pela técnica dela derivada constitui para Lima Vaz a maior ameaça da civilização ocidental. ${ }^{41}$

As consequências éticas dessa postura se revelam acima de tudo em seus efeitos profundos no nosso universo simbólico: “... desaparecida aos olhos da razão a medida axiológica da realidade em cujo horizonte se eleva a ideia do ser como bem-em-si, não resta ao agir humano senão a errância no espaço anômico do niilismo", ${ }^{42}$ um episódio fatal que está avançando nos estratos profundos da história espiritual do Ocidente. Os princípios do agir humano são agora buscados nos mitos do prazer, do consumo e da liberdade absoluta, pois é no mundo do mito em que se situa agora a metafísica expulsa da esfera da razão. Daí a pergunta de fundo de nossa civilização pós-metafísica: "Irá a objetividade técnica oferecer-se, finalmente, como único alimento à carência metafísica do nosso espírito?" ${ }^{43}$

38 Ibid. 255.

${ }^{39}$ Cf. LIMA VAZ H. C. de, Presença de Tomás de Aquino no horizonte filosófico do século $X X I$, op. cit, p. 266.

${ }^{40}$ Cf. RIBEIRO E. V., Reconhecimento ético e virtudes, São Paulo: Loyola, 2012, p. 76-77.

${ }^{41}$ Cf. LIMA VAZ H. C. de, A Metafísica na Modernidade, op. cit., p. 366.

${ }^{42}$ Cf. LIMA VAZ H. C. de, Esquecimento e Memória do Ser, op. cit., p. 283. 
A incapacidade da tecnociência para unificar e satisfazer exigências e tendências constitutivas de uma existência humana autêntica já se mostra para Lima Vaz no problema teórico de fundo da modernidade que é a irredutibilidade da existência à razão operacional que pode "representar, explicar, transformar, modificar, organizar, projetar. Mas não pode criar". ${ }^{44}$ Daí o caráter paradoxal da razão moderna que se faz capaz de envolver todas as dimensões da vida humana numa imensa ação de racionalização, que tem um enorme impacto sobre os critérios profundos de avaliação da própria existência, mas que se revela incapaz de dar conta do simples ato de existir o que a torna fonte de uma onda incontrolável de irracionalismo que perpassa as sociedades modernas e se expressa em suas crenças, em suas propostas filosóficas, em suas ideologias e em sua condução política.

Em seu fazer-se essa atividade abstrai metodologicamente de qualquer questão metafísica, mas não pode deixar de pressupor, pois do contrário ela seria impossível, o existir do sujeito racional no mundo, o seu existir como dado a si mesmo, ou seja, ela não pode existir sem pressupor o que Lima Vaz denomina a situação ôntica primária que não é objeto de consideração pela razão científica em que se dá primazia ao funcional e ao operacional. Eliminada a fonte última de inteligibilidade, o Esse absoluto e transcendente, seu substituto, a razão finita, vai necessariamente ter que conviver com a sem razão do simples existir que é irredutível a seus procedimentos operacionais, pois "quem poderá reivindicar, na imanência, o estatuto ontológico do Absoluto, por definição transcendente, e inalcançável na sua realidade em si pela razão discursiva que trabalha com conceitos finitos e relativos?"45

É precisamente isso que ele denomina a dramática situação intelectual e espiritual do homem moderno que se explicita teoricamente nas filosofias do absurdo e praticamente em condutas niilistas. A grande alternativa a essa situação implicaria um retorno à metafísica do esse ${ }^{46}$ "afirmado como primeiro na ordem da inteligibilidade e do ser como "primum logicum e primum ontologicum". ${ }^{47}$ Assim, a retomada da memória metafísica ${ }^{48}$ é a tarefa maior da filosofia em nossos dias.

\footnotetext{
${ }^{43}$ Cf. LIMA VAZ H. C. de, Presença de Tomás de Aquino no horizonte filosófico do século $X X I$, op. cit, p. 267.

${ }^{44}$ Cf. LIMA VAZ H. C. de, A Metafísica em questão, op. cit., p. 102-103.

${ }^{45}$ Cf. LIMA VAZ H. C. de, Essência e Existência, op. cit, p. 168.

${ }^{46}$ Cf. LEOPOLDO F., Notas para um estudo dos procedimentos metódicos em Lima Vaz: singularidade e transcendência na apreensão das ideias filosóficas, in: Síntese v. 30 n. 97 (2003) p.150: “... somente nos apossamos verdadeiramente da herança quando tornamos as questões herdadas do passado nossas questões, isto é, quando traduzimos aquilo que o passado interrogou em termos de nossas próprias perplexidades".

${ }^{47}$ Cf. LIMA VAZ H. C. de, A Metafísica em questão, op. cit., p. 103.

${ }^{48}$ Cf. DRAWIN C. R., Henrique Vaz e a opção metafísica, in: Síntese v. 29 n. 94 (2002) p.162: "Foi essa fina sensibilidade em relação às expectativas e aos impasses do mundo contemporâneo, sempre atenta às aporias que se entreteciam no coração da modernidade, que alimentou a opção vaziana e a transformou numa concepção axial em torno da qual foi construída uma obra de excepcional vigor e invejável coerência interna".
} 


\section{2) O Desafio de uma inversão radical da postura moderna: a retomada da Metafísica do Esse e a estrutura inteligível do ser finito}

A consideração do núcleo teórico da filosofia moderna nos conduz ao enorme desafio de recuperar teoricamente em situações muito diferentes o que constituiu o cerne do pensamento metafísico ocidental. Isso significa dizer que não se trata aqui de uma simples repetição, mas de um repensar a estrutura básica da metafísica no contexto de uma situação gerada pela própria filosofia moderna que constitui em relação ao pensamento clássico um paradigma alternativo no que diz respeito à questão fundamental da filosofia, ou seja, a inteligibilidade última do existir. ${ }^{49}$

O ponto de partida é a morte da metafísica no mundo simbólico de nossa cultura, ou como prefere dizer Lima Vaz, seu "retraimento epocal" 50 que para ele é o resultado de um longo itinerário intelectual de "desconstrução" que teve seu início no nominalismo tardo-medieval e que teve como resultado a deposição do lugar eminente que a metafísica ocupava na tradição da cultura ocidental o que configura nossa época como "pós-metafísica".

Depois de sua inauguração com o pensamento de Parmênides, a metafísica produziu para Lima Vaz três modelos fundamentais: o modelo platônicoaristotélico, o neoplatonismo e a filosofia tomásica. No sentido teórico, podemos dizer que na realidade temos duas propostas fundamentais: a metafísica da essência que caracteriza os dois primeiros modelos e a metafísica do ato de existir própria ao pensamento de Tomás de Aquino.

A metafísica do Esse como ela se elaborou no pensamento de Tomás de Aquino contém dois momentos profundamente concatenados entre si: 1) O momento noético que trata da emergência do esse no interior do juízo no final do processo abstrativo que se exprime na noção do esse commune; 2) $\mathrm{O}$ momento propriamente metafísico que trata da inteligibilidade absoluta do esse que, então, passa a ser designado como "Ipse esse subsistens".

O pensamento cristão medieval que se articulou no quadro teórico elaborado pelos gregos, primeiramente no modelo platônico (o modelo da ideia separada da ontologia platônica) e neoplatônico, depois no modelo aristótelico (o modelo da forma substancial da ontologia aristotélica) se confrontou com uma questão absolutamente central seja para a compreensão da realidade enquanto tal, de modo especial para a compreensão da

\footnotetext{
${ }^{49}$ Cf. HERRERO F.J, A recriação da tradição na antropologia filosófica de Pe. Vaz, in: Síntese v.30 n.96 (2003) p.10: "Mas ele não se deixa intimidar com o interdito moderno e contemporâneo da metafísica. Para ele a metafísica, ou melhor dizendo, a ontologia, é uma dimensão irrenunciável da filosofia, sob pena de abandonar o mais específico dela, a tematização do todo, por mais difícil que isso possa ser nas condições históricas atuais"

${ }^{50}$ Cf. LIMA VAZ H. C. de, Filosofia e Cultura: Perspectiva Histórica, op. cit., p.305.
} 
estrutura inteligível do ser finito, seja para a articulação compreensiva do conteúdo da fé cristã: a questão da distinção radical entre o Esse absoluto e os esse relativos, ou seja, na linguagem da teologia cristã, da distinção entre Deus e as criaturas.

Tomás situando-se no modelo conceptual tanto do platonismo/ neoplatonismo quanto da recepção do modelo aristotélico vai partir da crítica aristotélica ao relativismo sofista que desembocou através do argumento de retorsão na necessidade absoluta da afirmação por parte da inteligência de uma determinação em seu objeto e assim de sua introdução na ordem do ser e da unidade o que ocorre no juízo. ${ }^{51}$ "Enquanto absolutamente inteligível, o esse (einai, on) reivindica sua identidade com o intelecto no ato mesmo em que é intuído. Esse e pensar coincidem, portanto, numa unidade absoluta". ${ }^{52}$ Dessa forma o ser se revela como a primeira determinação do objeto da inteligência, ou seja, ao afirmar seu objeto a inteligência se instala imediatamente no reino do ser o que ocorre segundo o primeiro princípio fundado na oposição entre ser e não-ser e que manifesta para Lima Vaz uma abertura intencional à infinitude do ser que não pode ser negada sem autocontradição. ${ }^{53}$

O juízo humano é, assim, um ato complexo com muitos níveis. Num primeiro momento, a inteligência humana começa situando seu objeto no plano da necessidade inteligível, ou seja, do universal, e ela o faz através de uma dissociação do momento formal e qualitativo da coisa (o eidos, a essência) de sua singularidade material. Trata-se nesse primeiro momento da conquista de um plano de perfeição formal através de que todos os seres se caracterizam. No entanto, esse eidos isolado da matéria só é predicável nos juízos de realidade enquanto de alguma forma reintegrado na unidade concreta em que objetivamente se realiza. Isso significa dizer que num segundo momento a inteligência busca conquistar a unidade em que o ser do objeto se constitua como tal, assim que o primeiro plano da unificação é um retorno ao individual concreto. Dessa forma, o eidos alcançado é reintroduzido na matéria.

\footnotetext{
${ }^{51}$ Cf. AQUINO M. F. de, Experiência e Sentido II, in: Síntesev. 17 n. 50 (1990) p. 32 e ss.

${ }^{52}$ Cf. LIMA VAZ H. C. de, Ideia e Existência, in: Raízes da Modernidade, op. cit., p. 105. A respeito da interpretação do esse entre os escolásticos do século passado cf. KELLER, A., Sein oder Existenz? Die Auslegung des Seins bei Thomas von Aquin in der heutigen Scholastik, München: Pullacher Philosophische Forschungen, 1968.

${ }^{53}$ Cf. Cf. LIMA VAZ H. C. de, Transcendência : Experiência Histórica e Interpretação Filosófico-teológica, in: Síntese v. 19 n. 59 (1992) p. 448: “... e como poderia ser negada sem ter sido pensada, isto é, de alguma maneira afirmada?... a evidente finitude do nosso espírito, situado na contingência do Mundo e da História, só pode comportar-se com a sua também evidente infinitude intencional, atestada no pensamento do Ser, se aceitarmos obedecer à exigência lógica e existencial de afirmar o Transcendente como Absoluto do ser".
} 
É a partir daqui que Tomás de Aquino vai dar o passo decisivo para além de Aristóteles. ${ }^{54}$ Em primeiro lugar, o juízo mostra uma pluralidade de determinações formais no objeto e é justamente sobre essa pluralidade que o juízo exerce sua função de síntese. O núcleo ontológico capaz de suportar essa pluralidade de determinações e unificá-las é para Aristóteles e Tomás a substância. ${ }^{55}$ Assim, Tomás aceita de Aristóteles a tese de que na ordem das determinações formais das coisas a categoria ontológica fundamental é a categoria de substância de modo que ela é a expressão da ordem substancial das coisas, a unidade de base na ordem formal e, por conseguinte a fonte última de inteligibilidade. Até aqui vai Aristóteles: “O ser se revela no juízo como síntese do uno e do múltiplo na ordem das determinações formais em que o objeto se exprime". ${ }^{56}$

O que constitui, porém, a absoluta originalidade do pensamento de Tomás de Aquino e que o conduz a um último grau de inteligibilidade na compreensão dos seres é que ele se eleva a um plano supremo de unificação além do plano formal da substância situado no nível da essência em que se deteve o pensamento grego (o paradigma da primazia essência em metafísica). Ora se a própria tradição grega havia compreendido que o específico do ato do juízo é a afirmação do ser, ${ }^{57}$ então, para Tomás isso significa dizer que através desse ato a inteligência humana insere seu objeto na esfera da existência. ${ }^{58}$ Daí a afirmação central e decisiva para todo o pensamento de Tomás: o termo próprio do juízo, o ponto de partida da

\footnotetext{
${ }^{54}$ Cf. AQUINO M. F. de, Experiência e Sentido II , op. cit., p. 47: “Com sua metafísica do ato de existir, Tomás cumpre uma viragem epocal no pensamento filosófico, elevando a unificação do objeto a um nível de inteligibilidade inalcançado pela ontologia clássica grega".

${ }^{55}$ Não há no pensamento de Lima Vaz um confronto explícito com as críticas de ordem epistemológica e ontológica que já se iniciaram no pensamento dos empiristas ingleses ao conceito de substância nem também com as tentativas de sua reabilitação no pensamento contemporâneo, por exemplo, em Strawson e Kripke e com as teorias alternativas. Cf. a respeito desta problemática: ANGELELLI I., Handbook of metaphysics and ontology, München: Philosophia Verlag, 1991. IMAGUIRE G., A Substância e suas alternativas: feixes e tropos, in: IMAGUIRE G./ ALMEIDA C. L S. de/ OLIVEIRA M. A de (orgs.), Metafísica Contemporânea, Petrópolis: Vozes, 2007, p. 271-289. PUNTEL L. B, O Conceito de categoria ontológica: um novo enfoque, in: Kriterion n. 104 (2001) p.7-32; Estrutura e Ser. Um quadro referencial teórico para uma filosofia sistemática, São Leopoldo: Ed. UNISINOS, 2008, p. 251 e ss.

${ }^{56}$ Cf. LIMA VAZ H. C. de, Itinerário da ontologia clássica, in: Escritos de Filosofia VI. Ontologia e História, op. cit., p. 72.

${ }^{57}$ Cf. LIMA VAZ H. C. de, A Metafísica em questão, op. cit., p. 95: “Do ponto de vista metodológico, nosso roteiro procede inicialmente seguindo a chamada via compositionis: parte da intuição e afirmação originárias do esse e desenvolve as implicações lógico-dialéticas dessa posição inicial. Ao termo do percurso, novamente nos encontramos no princípio, obedecendo a uma modalidade da via resolutionis, que é ao mesmo tempo instauração de uma totalidade de estrutura dialética".

${ }^{58}$ Cf. LIMA VAZ H. C. de, Filosofia e Cultura: Perspectiva Histórica, op. cit., p. 322: “... ao ser submetido ao dinamismo da afirmação, o juízo transgride a limitação eidética da síntese concretiva, e eleva o objeto ao nível da universalidade formal do ser (ens commune), o que implica por sua vez referi-lo ao Absoluto real (Ipsum esse subsistens) que é posto (função tética do juízo) como finalidade última do dinamismo intelectual".
} 
metafísica, não é a essência, mas a existência, ${ }^{59}$ o "esse rei" que assim se constitui como a fonte primeira de inteligibilidade do ser finito. Sua estrutura metafísica se constitui como "passagem da síntese concretiva ou da representação ao ser e do ser ao Absoluto", 60 da forma ao ato de ser e do ato de ser ao Absoluto.

Ora, a existência é o ato primeiro, a perfeição de todas as perfeições, do ponto de vista epistemológico horizonte inteligível último de nossa inteligência. Ao contrário do que ocorre numa ontologia essencialista, Tomás de Aquino vai encontrar no ato de existir o grau supremo de inteligibilidade e por isso é no juízo que se opera a última conquista da unidade visada pela inteligência humana desde o princípio de sua atividade. ${ }^{61}$ "Toda experiência humana desenha-se no espaço do horizonte objetivo e onicompreensivo do ser" ${ }^{\prime 2}$ Dessa forma, seu quadro teórico metafísico se caracteriza pela primazia do ser e inaugura uma nova figura da metafísica.

É a partir daqui que Tomás vai elaborar sua concepção do ser em seu todo e, portanto, sua concepção da distinção entre Deus e suas criaturas. $\mathrm{O}$ quadro conceptual em que ele articula seu pensamento é a teoria aristotélica da forma e da matéria ou mais geralmente do ato e da potência. Neste contexto a estrutura especifica do ser finito se explica pela composição de um princípio potencial que suporta sua forma, ou seja, sua perfeição própria que é assim recebida nele. Numa palavra, o finito se caracteriza pela composição entre forma e princípio receptivo, trata-se, portanto, do modelo composicional da compreensão do ente, de uma "ontologia composicional", e assim, através desse modelo, exprime-se a inteligibilidade intrínseca do ser criado e sua distinção com o Criador.

Tomás de Aquino avança nesta ontologia na medida em que admite um plano ontologicamente mais profundo de composição: o da forma (essência) e do ato de existir (esse) e através disso ele supera de forma radical toda forma de ontologia essencialista que caracterizou o pensamento grego. Assim, por exemplo, para Platão, a inteligibilidade do ser provém da forma ou ideia e a finitude dos seres é uma consequência de sua participação na forma exemplar. Essa tese da limitação da inteligibilidade do ser

\footnotetext{
${ }^{59}$ Como também é o núcleo fundamental de todo o pensamento de Lima Vaz. Cf. SAMPAIO R. G., Metafísica e Modernidade, op. Cit., p. 323: "Seja como ponto de chegada, seja como ponto de partida a metafísica do existir organizada dialeticamente em Raízes da Modernidade é a chave de inteligibilidade, é a clef de voûte de todo o pensamento vaziano".

${ }^{60}$ Cf. LIMA VAZ H. C. de, Filosofia e Cultura: Perspectiva Histórica, op. cit., p. 322.

${ }^{61}$ Cf. HERRERO F.J, op. Cit., p. 11: “É com esta compreensão do ser como fonte, como pura positividade, como pura gratuidade e superabundância que o Pe. Vaz re-atualiza e refaz a experiência filosófica dos gregos, completada por Santo Tomás com sua compreensão do ato de ser como existir (Esse)" ...

${ }^{62}$ Cf. LIMA VAZ H. C. de, Mística E Política: A Experiência Mística Na Tradição Ocidental, in: Síntese v. 19 n.59 (1992) p. 494.
} 
finito à esfera da essência era tese comumente aceita pelos neo-aristotélicos medievais até porque Aristóteles também permaneceu no nível da inteligibilidade da essência em sua concepção dos entes.

Aristóteles entende a forma como ato da matéria nas substâncias compostas do mundo sublunar o que faz com que seu conhecimento seja fruto de um processo de abstração que produz a forma abstrata universal na inteligência ou como ato subsistente nas substâncias simples. Neste contexto, a forma se apresenta em dois estados: ou como parte inteligível do composto, como sua quididade, ou como o todo, a forma de uma matéria comum, e enquanto tal uma essência abstrata predicável do indivíduo. Nesse quadro conceptual não se põe a questão da inteligibilidade "intrínseca e fundante" 63 do ato de existir.

A ontologia de Tomás parte da pergunta básica a partir de onde se articulou esse pensamento: como explicar o ser finito? Como pensá-lo na dialética da dependência e da independência em relação ao ser infinito? Como atribuir-lhe consistência própria? É justamente aqui para Lima Vaz na questão da estrutura inteligível do ser finito que Tomás manifesta sua singular originalidade no pensamento metafísico ocidental na medida em que ele empreende uma "terceira navegação" 64 "avançando além da inteligibilidade da essência e fundamentando a consistência ontológica do ser finito na inteligibilidade fontal do esse ou do ato de existir" 65 o que para Lima Vaz constitui o tema primordial de sua metafísica ${ }^{66}$ e que só pode ser articulado de forma adequada num discurso de natureza dialética. Tomás conhece dois caminhos para a articulação da metafísica: ${ }^{67}$ a "via descendente" que parte da intuição do Absoluto $^{68}$ presente na afirmação do ser no juízo e explicita essa afirmação nas noções transcendentais que constituem o núcleo elementar de inteligibilidade de qualquer ser. Por sua vez a "via ascendente" parte da apreensão imediata do ser no mundo sensível e se eleva à suprema universalidade do ser expressa no conceito do ser enquanto ser.

"Como ato ou perfeição última, o esse é intuído na forma da oposição dialética entre o Esse absoluto e os esse relativos, da qual parte todo o

${ }^{63}$ Cf. LIMA VAZ H. C. de, Essência e Existência, op. cit, p. 154.

${ }^{64}$ Cf. POSSENTI V., A aliança socrático-mosaica - Pós-metafísica, Deselenização, Terceira Navegação, in: Síntese v.36 n. 116 (2009) p. 325-353.

${ }^{65}$ Cf. LIMA VAZ H. C. de, Essência e Existência, op. cit, p. 153.

${ }^{66}$ Cf. SAMPAIO R. G., Metafísica e Modernidade, op. cit., p. 173: "Todos os outros temas partem da metafísica do existir e retornam à metafísica do existir".

${ }^{67}$ Cf. LIMA VAZ H. C. de, Ser e Participação, op. cit., p. 179.

${ }^{68}$ Cf. SAMPAIO R. G., Metafísica e Modernidade, op.cit., cf. p.321: “O discurso metafísico já tem seu início com a questão do Absoluto. Mas ele também apresenta uma evolução e uma seriação de categorias que parte da pré-compreensão do Absoluto, e culmina na demonstração da sua existência e na demonstração da sua natureza". 
discurso metafísico" ${ }^{69}$ Numa palavra, a intuição originária ${ }^{70}$ do esse como perfeição absoluta faz emergir imediatamente a oposição entre o esse infinito $^{71}$ e os esse finitos e a exigência teórica de fundamentar racionalmente tanto a unidade como a separação dessas duas figuras do esse, pois "a afirmação de uma inteligibilidade radical do ser implica a afirmação de uma Inteligência absoluta como fonte primeira da inteligibilidade, da qual participa o próprio sujeito afirmante enquanto sujeito finito" ${ }^{72}$

Dessa forma, o esse finito se revela como o termo da relação de causalidade que constitui sua dependência estrutural do Ser Infinito. A inteligibilidade do ser finito se situa inteiramente no seio dessa relação que Lima Vaz denomina num sentido original e único de "relação transcendental" e isso constitui o cerne da solução teórica dada por Tomás de Aquino a mais profunda das interrogações humanas ${ }^{73}$ que permite "pensar o Absoluto em si e os seres relativos tanto na sua consistência própria quanto na sua total dependência do Absoluto". ${ }^{74}$ A teoria que pretende pensar o ser em seu todo se depara logo de entrada com grandes aporias: o uno e o múltiplo, o absoluto e o relativo, o necessário e o contingente. A solução dessas aporias posta por Tomás de Aquino consistiu em pensar a "oposição dialética" entre o ato de existir (esse) como perfeição absoluta e o ato da essência (eidos) como perfeição relativa, fonte da diferença dos seres entre si, que, por outro lado, se integram entre si por sua essência e pelo seu esse na ordenação dinâmica do universo para o Ser infinito. Dessa forma, a composição real da essência e da existência constitui a razão da contingência e da finitude dos seres criados. Com isso para Lima Vaz Tomás de Aquino conseguiu assegurar tanto a transcendência infinita do

\footnotetext{
${ }^{69}$ Cf. LIMA VAZ H. C. de, Essência e Existência, op. cit., p. 157.

70 Não se trata aqui para Lima Vaz de uma intuição a priori. Cf. LIMA VAZ H. C. de, $O$ Problema da Criação, in: Raízes da Modernidade, op. cit., p. 129: “A intuição do esse não é, portanto, uma intuição pura, a priori. Ele é mediatizada pela apreensão do sensível e pela abstração do ser-em-comum, sobre o qual tem lugar a separatio judicativa e a intuição protológica do esse como ato".

${ }^{71}$ Nisso se revela a relação de transcendência como constitutivo ontológico do ser humano como ser espiritual. Cf. LIMA VAZ H. C. de, Transcendência: Experiência Histórica e Interpretação Filosófico-teológica, in: Síntese v. 19 n. 59 (1992) p. 444: “... a relação de transcendência exprime, na verdade, o excesso ontológico pelo qual o sujeito se sobrepõe ao Mundo e à História... e, assim, avança além do ser-no-mundo na busca do fundamento último para o $E u$ sou primordial que o constitui". Cf. p. 447: "Desta sorte, a reflexão sobre a transcendência longe de ser um caminho de alienação, faz-nos descer às raízes do nosso ser, onde o Absoluto está presente como princípio fontal".

${ }^{72}$ Cf. LIMA VAZ H. C. de, Ideia e Existência, op. cit., p. 109.

${ }^{73}$ Cf. LIMA VAZ H. C. de, Filosofia e Cultura: Perspectiva Histórica, op. cit., p. 325-326: “... a posição do ser como existir no juízo objetivo, permaneceria inexplicável sem a presença, no movimento da inteligência, de uma finalidade antecedente e consequente, de um Princípio primeiro e de um Fim último da nossa atividade intelectual que, sendo a universalidade absoluta do ser o horizonte da afirmação, não pode ser senão o Absoluto real".

${ }^{74}$ Cf. LIMA VAZ H. C. de, Essência e Existência, op. cit., p. 154-155.
} 
Esse absoluto como manter "a distinção e a autonomia dos seres finitos na sua relação transcendental de dependência para com o Esse infinito". ${ }^{75}$

Que razões levaram Tomás de Aquino a romper com a ontologia essencialista? Em primeiro lugar o encontro entre as duas tradições que estão na base da formação do mundo simbólico do ocidente: por um lado, a tradição teológica da exegese do nome de Deus como aparece no Êxodo, portanto, a tradição do cristianismo; por outro, a tradição noplatônica que concebia o ser em seu todo como um universo hierárquico coroado por um princípio que Porfírio denominou o Existir (to eînai).

Na realidade, Tomás de Aquino não escreveu nenhum artigo para explicitar sua metafísica do esse, o que mostra o imenso trabalho especulativo de Lima Vaz e de muitos outros intérpretes de Tomás no século XX para elaborar essa concepção a partir dos inúmeros textos de Tomas. No entanto, para Lima Vaz tudo se passa como se uma intuição básica alimentasse uma evidência presente no fundamento dos grandes problemas metafísicos: o evento metafísico fundamental da afirmação do esse no juízo "alguma coisa é". Essa evidência básica é sempre retomada, embora permaneça perdida na banalidade de nossa linguagem e de nossos pensamentos na vida quotidiana.

Para Lima Vaz, para além daquilo que o próprio Tomás (que se utilizou de instrumentos lógicos analíticos) foi capaz de captar, é a natureza dialética da relação entre o Esse absoluto e os esse relativos, por um lado, e a oposição intrínseca no ser finito entre essência e existência, por outro, que nos faz compreender o enorme passo que foi dado na metafísica com a metafísica do esse. Lima Vaz entende "dialética"76 acima de tudo como método, isto é, como um procedimento conceitual através de que se exprime a inteligibilidade de qualquer realidade, portanto, é o método específico de uma consideração ontológica, e que caminha através de oposições apresentadas tanto na ordem real como na nocional que o logos integra numa ordem superior. ${ }^{77}$

Para ele, o procedimento dialético não é um instrumento externo aplicado a um conteúdo, mas é a própria lógica intrínseca desse conteúdo, a expressão do dinamismo de sua inteligibilidade. $\mathrm{O}$ método dialético ${ }^{78}$ parte do

\footnotetext{
${ }^{75}$ Cf. LIMA VAZ H. C. de, Essência e Existência, op. cit., p. 166.

${ }^{76}$ Cf. MAC DOWELL J. A., Método Dialético, História e Transcendência no Sistema Filosófico de Henrique de Lima Vaz, op. cit., p. 224-229.

77 A respeito de sua concepção do que ele considera os dois modelos básicos do pensamento dialético. Cf. LIMA VAZ H. C. de, Filosofia e Cultura: Perspectiva Histórica, op. cit., p. 16-76. Para uma crítica do modelo hegeliano cf. PUNTEL L. B., É possível aclarar o conceito de dialética em Hegel, in: Em busca do objeto e do estatuto teórico da filosofia. Estudos críticos na perspectiva histórico-filosófica, São Leopoldo: Ed. UNISINOS, 2010, p. 201-219.
} 
conteúdo inteligível mais elementar, a afirmação: alguma coisa é. Através do argumento de retorsão é suprassumida a oposição mais primitiva, a oposição do ser ao nada, que se exprime logicamente pelo princípio de não-contradição. A partir desse fundamento se forma a oposição do uno e do múltiplo que dá início ao caminho da reflexão metafísica até culminar na dialética do Ser absoluto e os entes finitos e relativos.

\section{3) O Esse absoluto como criador do Mundo}

A metafísica do esse levou Tomás a pensar o ser em seu todo como a bidimensionalidade de esse absoluto e esse relativos, pois a exigência do Absoluto transcendente está inscrita na própria essência e no dinamismo profundo da razão. A questão que se põe agora é: como pensar mais concretamente a relação transcendental entre o Esse absoluto e os esse relativos? Como pensar a origem do ser finito e a ordem do universo? Tomás de Aquino enfrenta essa problemática a partir de quatro categorias ontológicas: inteligência, liberdade, necessidade e contingência.

O método dialético mostra-se fundamental para compreensão ontológica adequada dessa realidade. As relações entre essas categorias constituem uma oposição dialética. Assim, a inteligência se opõe dialeticamente à liberdade e à contingência, como a liberdade se opõe dialeticamente à inteligência e à necessidade. No Esse absoluto, onde há identidade entre esse e essência só há distinção de razão entre os quatro termos o que significa dizer que o Esse reúne em si os quatro aspectos distintos, o que permite pensar a relação transcendental como uma relação de criação enquanto relação não-recíproca entre o Esse absoluto e os esse relativos, pois a simplicidade absoluta do Esse criador exclui qualquer relação real com a multiplicidade dos esse finitos. "A metafísica do esse permite, desta sorte, pensar na sua radicalidade o problema da origem dos seres, ao formulálo a partir de sua identidade mais profunda como existentes" ${ }^{\prime 79}$

A criação é, então, pensada no sentido estrito de um pôr os esse relativos na existência. De um lado, temos o Esse absoluto que permanecendo em sua distância ontológica infinita profere em sua inteligência as ideias e contém em sua liberdade infinita a potência infinita de suscitar os seres finitos do nada, isto é, sem qualquer substrato pré-existente. Esses seres enquanto são postos na existência (causalidade eficiente) pela própria li-

\footnotetext{
${ }^{78}$ Lima Vaz não se confrontou explicitamente com as tentativas que emergiram no século XX para determinar a natureza lógica, epistemológica e metafísica da dialética. Cf. WANDSCHNEIDER D. (org.), Das Problem der Dialektik, Bonn: Bouvier, 1997. OLIVEIRA M. A. de, Dialética Hoje: lógica, metafísica e historicidade, São Paulo: Loyola, 2004.

${ }^{79}$ Cf. LIMA VAZ H. C. de, O Problema da Criação, op. cit., p. 134.
} 
berdade do Esse absoluto (causalidade final do Bonum, ou seja, "da livre ordenação com que o esse participa da Liberdade infinita" ${ }^{80}$ ) participam por sua essência das ideias da inteligência absoluta (causalidade formal do Verum, ou seja, da necessidade intrínseca da essência que como tal participa da Ideia na Inteligência infinita $\left.{ }^{81}\right) .{ }^{82}$

A verdade e o bem constituem os pilares da metafísica tomásica da participação. "Portanto, não é por indigência, mas por superabundância de Bondade que o Bem infinito se comunica ad extra, verificando-se aqui o axioma neoplatônico frequentemente comentado na tradição medieval: Bonum est diffusivum sui" ${ }^{83} \mathrm{Com}$ isso a concepção da realidade enquanto tal chega a seu patamar último: "Toda a realidade está aqui concentrada na relação de criaturalidade pela qual o ser finito subsiste na unidade do seu esse e da sua essentia (relação de diferença na unidade) na radical dependência do Esse infinito" ${ }^{84}$ Assim, a relação é pensada dialeticamente no sentido de que a oposição é suprimida pelo Esse absoluto sem que seja eliminada sua distância ontológica infinita.

Com isso Tomás de Aquino foi capaz de pensar numa unidade na diferença o que parecia inconciliável no esquema do essencialismo. O finito só pode ser pensado através dessa supressão da oposição e nessa supressão. Isso significa dizer que ele é absolutamente distante do esse absoluto que enquanto tal é radicalmente distinto de toda e qualquer realidade finita; por outro lado, infinitamente próximo dele em virtude da imanência do Esse absoluto que lhe dá seu esse como ato fundante do seu ser sem o que ele retornaria ao nada. É precisamente essa inclusão na esfera do Infinito que firma o finito em seu existir próprio, tanto na originalidade de sua forma específica como participação ${ }^{85}$ na ideia da inteligência infinita, como na manifestação da gratuidade do seu ser recebido da liberdade absoluta. Do ponto de vista epistemológico constitui o "fundamento da predicação analógica entre o Esse subsistente participado (Deus) e os esse participantes (criaturas)" ${ }^{86}$

Com isso são garantidos teoricamente tanto a transcendência infinita do Esse absoluto como a distinção e a autonomia dos esse finitos. Esse é também o horizonte de determinação daquele âmbito que constitui o ob-

${ }^{80}$ Cf. LIMA VAZ H. C. de, Ser e Participação, op. cit., p. 181.

81 Ibid.

${ }^{82}$ Cf. LIMA VAZ H. C. de, Ser e Participação, op. cit., p. 177.

${ }^{83}$ Cf. LIMA VAZ H. C. de, Ser e Participação, op. cit., p. 181.

${ }^{84}$ Cf. LIMA VAZ H. C. de, Essência e Existência, op. cit.,p. 159.

${ }^{85}$ Lima Vaz distingue dois níveis de participação. Cf. LIMA VAZ H. C. de, Ser e Participação, op. cit., p. 178: "Há, pois, uma participação formal dos seres no Ser enquanto noção universalíssima (ens commune), e uma participação causal dos seres existindo concretamente (esse) no Esse infinito e absolutamente transcendente". Cf. SOUZA L. C. S. de, Natureza e Participação em Sto. Tomás de Aquino (de substantiis separatis, c.9), in: Síntese v.36 n.116 (2009) p. 385-397.

${ }^{86}$ Cf. LIMA VAZ H. C. de, Ser e Participação, op. cit., p. 185. 
jeto próprio da metafísica: a "totalidade dos seres finitos formalmente enquanto seres (entia ut entia) que subsistem na dependência causal do Esse infinito" ${ }^{87}$

\section{4) Aprofundamento da compreensão da estrutura ontológica do ser finito a partir da ideia da criação}

A determinação metafísica da relação transcendental abre espaço para uma leitura aprofundada da estrutura inteligível do ser finito. O ser finito enquanto finito só é pensável a partir de uma oposição intrínseca que se manifesta na forma de uma diferença na identidade, ou seja, a diferença entre a necessidade absoluta que é própria da essência na medida em que o ser finito participa $^{88}$ da ideia exemplar da inteligência infinita e a necessidade hipotética que é fonte da contingência ${ }^{89}$ com que o esse do ser finito é posto pela liberdade infinita "como semelhança participada da Bondade exemplar". ${ }^{90}$

Essa oposição que o caracteriza estruturalmente é supressa na identidade relativa em que o ser finito subsiste na sua unidade na medida em que ele recebe na perfeição de sua essência específica o ato supremo do existir, realidade pensada por Tomás no esquema aristotélico do ato (esse) e da potência (essência) que o constitui como ser composto distinto da simplicidade plena do Esse absoluto.

Trata-se aqui da distinção real de dois co-princípios metafísicos que asseguram justamente a unidade na diferença da estrutura metafísica do ser finito: o esse recebe sua perfeição específica da essência e a essência recebe do ato do esse sua perfeição última. Numa palavra, "pela existência o universal da essência está enraizado na singularidade ôntica pela qual o ser é si mesmo em sua identidade mais radical". ${ }^{91} \mathrm{O}$ ente, portanto, é inteligível a partir da realidade dos dois co-princípios, ou seja, de sua distinção real; do contrário não seria possível compreender a separação ontológica infinita entre o esse absoluto e os esse finitos, assim como ex-

\footnotetext{
${ }^{87}$ Cf. LIMA VAZ H. C. de, Ser e Participação, op. cit., p. 178.

${ }^{88}$ Para Lima Vaz o conceito de "participação" é um dos eixos de sustentação da metafísica de Tomás de Aquino. Ele chegou a esta problemática através do opúsculo De Ebdomadibus de Boécio. Cf. LIMA VAZ H. C. de, Ser e Participação, in: Raízes da Modernidade, op. cit., p. 172.

89 A utilização de categorias modais é central no pensamento de Lima Vaz. No entanto, não há um confronto explícito com o debate a respeito da lógica e da metafísica modais como eles se articularam no século XX. Cf. a respeito: HUGHES G. E./ CRESWELL J., A new introduction to modal logic, London/ New York: Routledge, 1996. PUNTEL L. B., Estrutura e Ser. Um quadro referencial para uma filosofia sistemática, São Leopoldo; UNISINOS, 2008, p. 586 e ss.

${ }^{90}$ Cf. LIMA VAZ H. C. de, Essência e Existência, op. cit.,p. 161.

${ }^{91}$ Cf. LIMA VAZ H. C. de, Ser e Participação, op. cit., p. 171.
} 
plicar a tensão que caracteriza a finitude enquanto finitude entre a necessidade da essência e a contingência do esse.

Com isso se explicitou o horizonte último de compreensão dos seres finitos: a verdade de sua estrutura ontológica manifesta sua inteligibilidade através da articulação com a verdade ontológica última, a verdade, como ideia na inteligência infinita (exemplaridade da ideia), e a bondade, que é inerente à sua forma enquanto perfeição específica de seu ser, através da articulação com a bondade ontológica última, "pela qual os esse finitos participam da exemplaridade da Bondade infinita" ${ }^{\prime \prime 2}$ (gratuidade da liberdade). ${ }^{93}$ Daí a suprema tensão dialética que marca o ser em seu todo entre a dissemelhança infinita e a semelhança analógica entre as duas figuras do esse. ${ }^{94}$

\section{5) A superação proposta por Tomás de Aquino é suficientemente radical?}

Uma questão central para um diálogo com o quadro teórico que constitui o núcleo do pensamento de Tomás e que é retomado no pensamento de Vaz é o que aqui se denominou de "ontologia composicional"95 que busca seus conceitos básicos (potência, ato, matéria, forma, ente, etc.) no quadro teórico da metafísica aristotélica enquanto ciência do ente enquanto ente mesmo reconhecendo a originalidade e o passo fundamental do pensamento de Tomás em relação a Aristóteles e todo o Essencialismo do pensamento grego por sua metafísica do esse enquanto ato do $\operatorname{ser}^{96} \mathrm{e}$ o fato de que sua posição seja incompreensível fora da influência marcante da tradição platônica e neoplatônica.

A tese central de Tomás é que o objeto específico do intelecto humano é o ente (De ver. q. 1 a.1) que é entendido como o "concreto", 97 isto é, como a conjunção do esse com algo que o recebe, ou seja, o ente é aquilo que tem esse, é um "composto" que é expresso especialmente em quatro pares de

\footnotetext{
${ }^{92}$ Cf. LIMA VAZ H. C. de, Essência e Existência, op. cit.,p. 160.

${ }^{93}$ Para Lima Vaz, essa tese é herança platônica. Cf. LIMA VAZ H. C. de, O Problema da Criação, op. cit., p. 131: “O modelo platônico legou à teologia cristã da criação duas contribuições doutrinais de fundamental importância: o exemplarismo, fundado na transcendência das Ideias, e o finalismo do Bem, que rege a ordem do mundo"

${ }^{94}$ Cf. SAMPAIO R. G., Metafísica e Modernidade, op. cit., p. 166; “... por relação de razão Lima Vaz compreende uma relação segundo a qual a inteligência finita pensa a Inteligência infinita como causa exemplar das criaturas e a Vontade divina como causa eficiente das criaturas".

${ }_{95}$ A respeito de uma consideração crítica com a semântica e a ontologia composicionais cf. PUNTEL L. B., Estrutura e Ser, op. cit., p. 247 e ss.

${ }_{96}$ Retomada por seus discípulos a partir dos anos 30 do século passado. Cf. FABRO C., "L'originalité de l'esse thomiste", in: Revue Thomiste 54 (1956) p. 240-270, 480-507. Cf. também seu livro: La nozione metafisica di partecipazione secondo S. Tommaso d'Aquino, 2a. ed.,Turin: SEI, 1950; GILSON É., L Être et l'essence ,Paris: Vrin, 1948.
} 
conceitos: "participans-participatum" (participante-participado), "potentiaactus" (potência-ato), "recipiens-receptum" (receptor-recebido), "habenshabitum" (O que tem/ o que é tido). O par conceitual "potência-ato" é o quadro ontológico superior: a matéria é a potência frente ao ato como sua forma. O passo decisivo de Tomás vai consistir em considerar a própria forma como potência frente a outro ato que é o esse enquanto ato de ser. Aqui a forma é a essência que é potência frente ao esse enquanto ato.

Esse esquema teórico é expresso em Tomás com toda clareza em afirmações como a do "De ente et essentia" c. 4: "Tudo o que recebe algo de outro está em potência em relação a este; e isto que é recebido por ele é seu ato". Assim, o esse é a concretização do ente de tal modo que ele só pode ser entendido a partir do esse e esta é uma posição que vai claramente além do quadro teórico herdado de Aristóteles. A questão central do pensamento tomásico é, então, como Tomás compreendeu o esse que constitui a categoria básica de sua metafísica.

Em primeiro lugar, numa perspectiva explícita, o esse é entendido como "ato de ser" enquanto o ato último, supremo ou mais profundo na hierarquia dos atos o que leva Tomás a dizer que ele é a atualidade de todos os atos, a perfeição de todas as perfeições ( $S c G$ I 38). Enquanto ato, o esse se distingue de outros fatores ontológicos como ente, essência, forma, sujeito, etc., ou seja, o esse é pensado como um momento distinto de outros momentos: o esse, enquanto ato, é outro em relação à essência e a essência outro em relação ao esse, o que significa dizer que o esse não os abrange ${ }^{98}$, ele não é aqui pensado como a unidade dos diferentes momentos.

Se o esse é o ato do ser, então, o "ipsum esse" é puro ato de ser. Portanto, Deus, ser absoluto, o "ipsum esse per se subsistens", é simples, o que implica identidade fundamental entre essência e esse e consequentemente "composição" no ser criado entre essência e esse. Dessa forma, no ser finito Tomás distingue duas dimensões ou duas ordens igualmente originais, a essencial e a existencial, sem que seja feita a pergunta explícita pela unidade originária dos dois momentos. A unidade dos dois momentos diferenciados não é tema específico de seu pensamento. Entendido dessa maneira, o pensamento do esse enquanto ato do ser, embora constitua um passo decisivo além da conceitualidade aristotélica não escapa à crítica heideggeriana à metafísica enquanto pensamento que tematizou o ente, mas é marcado fundamentalmente pelo "esquecimento do ser", pressu-

${ }^{97}$ Cf. PUNTEL L. B., O pensamento de Tomás de Aquino como pensamento sumário-irrefletido sobre o ser e a analogia, in: Em busca do objeto e do estatuto teórico da filosofia. Estudos críticos na perspectiva histórico-filosófica, São Leopoldo: Ed. UNISINOS, 2010, p. 55 e ss.

${ }^{98}$ Cf. PUNTEL L. B., Ser e Deus. Um enfoque sistemático em confronto com M. Heidegger, É. Lévinas e J.-L. Marion, São Leopoldo: Ed. UNISINOS, 2011, p. 59. 
pondo-se que Heidegger entende aqui ser não como o ato do ser enquanto um momento constitutivo do ente, mas como a esfera oniabrangente.

Por outro lado, há vários textos em Tomás que apontam para uma concepção de ser que vai além de sua concepção explícita como ato de ser, ou seja, que sugerem uma "concepção compreensiva" do ser enquanto conexão originária que, contudo, não foi de fato por ele expressamente desenvolvida. Por exemplo, sua afirmação de que nada externo ao ser pode ser acrescentado a ele já que nada pode ser externo a ele a não ser o não-ser (De pot. q. 7 a. 2 ad 9). O ser não pode ser diversificado por algo que esteja fora dele. Então, se é assim, como se pode compreender a distinção entre essência e esse? Que significa essência? Numa palavra, faltou no pensamento de Tomás de Aquino o desdobramento de uma concepção adequada do esse, pois normalmente o esse é pensado aqui como o polo objetivo sem que neste pensamento sejam de antemão incluídos o ser humano, o sujeito, a linguagem, etc.

Tomás de Aquino e, com ele, Lima Vaz apontam com razão para o caráter absolutamente fundamental da filosofia que se revela, então, como filosofia do ser. Avançar aqui, parafraseando Hegel, significa retornar ao fundamento, ou seja, retornar ao fundamento da "filosofia do ser" e pensar com rigor teórico aquilo que a metafísica tomásica e vaziana já intuíram e não desenvolveram: uma concepção compreensiva do ser entendido como a dimensão primordial, ou seja, enquanto a conexão de todos os elementos e de todas as configurações do universo irrestrito do discurso, numa palavra, enquanto a dimensão oniabrangente.

Assim se pode dar à metafísica a configuração possível e necessária no contexto teórico em que nos situamos hoje e dessa forma efetivar o traço fundamental da filosofia enquanto teoria compreensiva da realidade enquanto tal, ou seja, enquanto teoria do ser e si mesmo e em seu todo. A metafísica assim entendida tematiza a base de todas as teorias, tanto filosóficas como não filosóficas, uma vez que examina o que é fundamentalmente pressuposto por qualquer trabalho teórico e enquanto tal se revela como absolutamente indispensável para um pensamento crítico e racional. Ela é, como diz Lima Vaz, a proposta teórica de pensar a unidade profunda da realidade em seu todo. O pensamento vigoroso de Lima Vaz, ímpar no contexto brasileiro, significa um passo insuperável nessa direção.

Endereço do Autor:

Rua Catão Mamede, 218 apto. 603

60140-110 Fortaleza - CE

email: manfredo.oliveira@uol.com.br 